\title{
The Prodigal Son: Some Psychological Aspects of Augustine's Conversion to Christianity
}

\author{
Rein Nauta
}

Published online: 1 August 2007

(C) Blanton-Peale Institute 2007

\begin{abstract}
Augustine's conversion is considered exemplary for its Christian testimony. However, the psychological aspects are also relevant, for Augustine's conversion to Christianity was as much inspired by personal and cultural ambitions as by religious convictions. For Augustine, the conversion to the Christian faith spelled a life of asceticism-a life of celibacy, a virtuous and chaste existence, which also offered him a means of escape from the threatening ambiguity of parental relations and a chance to realize the cultural ideal of the civilized philosopher who has subjugated the passions of the flesh. In this paper we explore the psychological dynamics of the absent father, the suffering mother and the prodigal son and the role they played in Augustine's conversion to Christianity.
\end{abstract}

Keywords Conversion - Augustine - Absent father - Suffering mother ·

Narcissism

Augustine's active commitment to the Christian faith implies a personal conversion to a life of asceticism-a celibate life lived in honour of God and apparently considered as a victory over the corruptive desires of the flesh and the restiveness of the heart. Numerous scholars have tried to explain Augustine's dramatic transformation in thought and behaviour by exploring not only his religious sentiment and theological thinking, but also the characteristics of his personality and the relations with his parents and other self objects that helped to shape it (e.g. Brandle and Neidhart 1984; Capps and Dittes 1990; Jonte-Pace 1993; Capps and Miles 1994; Bavel 1997; Curtis 2003). Some authors have suggested that Augustine's conversion may be seen not only as the result of an inner struggle for religious wisdom and truth, or as a solution to the threatening ambiguity of parental relations, but also as the realization of the cultural ideal of the civilized philosopher who has mastered the passions of the flesh (e.g. Brown 1969, 1990). It is the demons of sexual lust and seductive

R. Nauta $(\square)$

Department of Religious Studies and Theology, University of Tilburg, P.O. Box 90153,

Tilburg 5000 LE, The Netherlands

e-mail: R.Nauta@UvT.nl 
concupiscence which appear, in particular, to hinder a life of moral rectitude and religious devotion. For Augustine, sexual desire is related to autonomy and creativity, but also to a loss of self-control, a failure of the will, and to shame about forbidden passions. In an attempt to find a solution to this ambivalence, Augustine embraced Christianity. Christ, born of a virgin and untainted by desire, serves as a model for the new life (Brown 1969, 393, 1990, 351).

However, it is not only the conditions and motives for his conversion that appear to be ambiguous and ambivalent; the effects and consequences are not without contradictions and contrasts either. After his conversion, when he has become his own man as a Christian, freed from heroes who fail, friends who disappoint and love tainted by sin, Augustine resigns himself to being a son forever, an ambiguous and anxious retreat into a life devoid of inner conflicts and worldly temptation. He avoids the company of women and fights any sign of autonomy and self-sufficiency he observes in others.

Any psychological interpretation of Augustine as a person presupposes that it is possible, with the help of current theories on personality development and the role of relations with parents and other self objects, to understand the dynamism of parental relations in earlier times without falling into a diachronic trap. Any such an attempt is not without risks and potential pitfalls (Berg 1956; Daly 1978; Frederiksen 1974; Newbold 1982; Weintraub 1978; Woolcott 1965). In a sense, these interpretations might tell us more about the person who provides the explanation and the time in which it is made, than about the object of the exegesis. The earlier interpretations of Augustine's conversion, for example, tend to emphasise autonomy and dependence and oedipal problems in his development (e.g. Capps 1983; Chomarat 1988; Elledge 1988; Kligerman 1957; Miles 1982; Pruyser 1966; Rigby 1985) while the later ones, in line with a shift in psychoanalytical interest, tend to stress issues of recognition and confirmation, problems of a narcissistic nature (e.g. Capps 1990; Capps and Dittes 1990; Capps and Miles 1994). All these different but plausible nuances of motives and feelings underline Augustine's complexity as a real human being. An analysis of the influence of the absent father and the suffering mother, as presented in his Confessions, may therefore shed more light on his conversion.

\section{The Absent Father}

To understand Augustine's youth, it is essential to get a better view of his parents. His mother takes pride of place in the Confessions, while his father is only mentioned as a secondary character. In Book IX of the Confessions, father and mother are compared:

...given in marriage when she reached a suitable age, she served this man "as her lord". She was eager to win him for Thee, speaking to him of Thee through her behaviour, in which Thou didst make her beautiful, reverently lovable, and wonderful to her husband. Thus she even put up with wrongs of infidelity never permitting any dissension with her husband as a result of such a matter. She looked forward to Thy mercy upon him, that he might become chaste as a believer in Thee. Moreover though he was outstanding for his kindness, he was also quick to anger. But she had learned not to oppose an angry husband, either by action or even by word. (IX, ix, 19)

In this quotation, in which Augustine commends the wisdom of Monica's (his mother) course of action, Patricius is portrayed as a kind-hearted but irascible man, to whom 
adultery was simply part and parcel of married life. Patricius appears to be in charge of the domestic arrangements: he is the quick-tempered pater familias who does as he pleases and ignores his wife's needs. In this scenario Monica would be the subservient housewife who is resigned to her husband's temper, tolerates his adulterous behaviour for the sake of peace and quiet, and only speaks when her husband has finished raging. Closer inspection however reveals another relationship: Patricius is like an overgrown child, a naive tyrant, who cannot control his fury and his passions, who likes to boast about his extravagant behaviour, but who is in fact steered and unobtrusively dominated at home by the wise wife, who accepts his quirks like a mother and corrects him time and again with diplomacy and love.

In present-day terms, one might describe Patricius as a typical representative of the machismo complex that still prevails in Mediterranean countries. The machismo complex is a "male-centred ideology that encourages men to be sexually aggressive, to brag about their sexual prowess and their genital attributes, and to dominate women sexually" (Carroll 1986; cf. Gilmore and Gilmore 1979; Saunders 1981). Patricius is the epitome of macho man. Ostensibly, he is the master of the house. His docile wife is constantly at his beck and call, and he gets away with making a pass at any woman he meets. He takes pride in both his own and his son's sexual prowess. The sight of his son having an erection in the bathhouse, "and saw me growing into a young man and taking on the appearance of a restless adolescence" (II, iii.6) fills him with fatherly pride and the prospect of progeny fills him with joy.

Saunders (1981) describes this Mediterranean machismo complex as a compensatory response to a conflict that men experience between an early feminine identification and later masculine role expectations. Apparently, this conflict particularly affects the sons of so-called father-ineffective families. In these families actual authority lies with the mother while the father plays a marginal role, not only in family matters but also in the economic sphere outside the confines of the family home. Sons who are raised in such families identify initially with their mothers. When they grow up, however, they discover that society expects them to display masculinity and behave like a man. Their early feminine identification makes them so insecure about their masculinity that they indulge in excessively masculine behaviour. This exaggerated and, at the same time, reductionist and simplified one-dimensional masculinity is the central element of the machismo complex.

The family in which Augustine grew up may be typified as father-ineffective. Patricius is an absent father, not only because he dies prematurely, but also because of his lifestyle. He prefers to spend his time in the company of male friends and other women, away from the constrictions of the family home. He is also absent in a figurative sense because he is unable to provide for the material needs of his family. To finance Augustine's education, for example, his parents need to turn to Romanianus who, like a local 'godfather', bestows his favours on Thagaste in a patronage system. This dependence on a benefactor shows up Patricius as an ordinary man of limited means, who is unable to finance his son's education despite boasting about his position as a civil servant and his achievements inside and outside the office. In the father-ineffective family, the oedipal, sexual attractiveness of the mother is great, and the interaction between mother and son is intense and all-embracing. Her closeness and lynchpin position feed the son's desire. The father's absence does not however mean he has relinquished his claim to the mother. In father-ineffective families, the father is also a rival, whose revenge is formidable if his territory is encroached upon. Although, to the outside world, the father, even when playing second fiddle in the confines of the home, appears to be setting the tone by bragging about his dubious achievements and his many adulterous conquests, it is still the mother who has the authority to protect the son against the threat emanating from the macho father. Although the adoption of her norms 
and values and the assertion of her authority deflect the threat of the father's vengeance, they promote at the same time the son's identification with the mother. In father-ineffective families, the son's desire for the mother is powerful but strongly repressed. Augustine grows up with a macho father and a mother who represents authority. Though Augustine identifies with his mother, he resembles his father. The family situation influences the son's sexual behaviour which manifests itself in an exaggerated masculine response to the feminine identification. This feminine identification, according to Dittes (1965), finds veiled expression in Augustine's emotional involvement with his friends and in a vehement and sensitive disposition.

At an early age, Augustine fathers a son, Adeodatus. In mid-adolescence, when his father is trying to find funds to finance his further education and Augustine has to stay at home for a year, he proves his masculinity: "I burned, at that time of my youth, with the craving for hellish satisfactions. I shamelessly permitted myself to run wild through divers and shady loves. My beauty wasted away and, while pleasing myself and desiring to give pleasure to the eyes of men, I became rotten before Thy eyes" (II, i, 1). Perhaps not much more than his peers, but certainly no less, Augustine abandons himself to the "mists of slimy concupiscence of the flesh and of the bubbling froth of puberty" (II, ii, 2).

His surrender to sensuality may have been — not least to himself-a form of strategic self-presentation (Goffman 1959), an attempt to prove his potent and powerful masculinity to those whose regard and esteem he desires. This narcissistic craving for admiration also expresses itself in his misdemeanours with his friends. In the Confessions he writes about the theft of some pears: "I certainly would not have done it alone. Therefore, I also loved in it the companionship of those with whom I did it" (II, viii, 16). In this period, during which his father publicly fails in his duties, Augustine's sexual excesses may also have been inspired by 'impression management': trying to convince his friends that he is not a softy.

Unlike her husband, Monica is not happy with her son's emerging sexuality. It frightens her: "She thus experienced a rising feeling of holy fear and trembling for me; though I was not yet one of the faithful" (II, iii, 6). Monica is afraid of her son's sexuality because, as a man, he may also threaten her: "For her desire it was, and she secretly reminded and most carefully admonished me, that I should not indulge in fornication and, above all, not commit adultery with the wife of any man" (II, iii, 7). Kligerman (1957) believes that Monica is afraid that she too might be an object of her son's sexual desire. In the act of warning him, she simultaneously pre-empts his potential advances.

In the father-ineffective family, the macho behaviour of the son is an overreaction to his strong ties with his mother. Though the son appears to be emulating the father, his existence is still dominated by the forbidden desire for the mother, with whom he identifies. The mother, by transferring her values and morals, forbids this desire and makes him repress it. In the process, she shields him from the father.

\section{The Suffering Mother}

In an oedipal reading of the parental influences, as expressed in Augustine's Confessions, the father plays a central role, largely because of his absence. In a narcissistic reading, the role of the mother is more pronounced. In such an interpretation it is not Augustine who cannot break away from the mother, but the mother who will not let go of the son. In this narcissistic reading, the tragedy of the mother-son relationship is thought to ensue from an unfulfilled desire for affirmation and recognition on the part of the mother. 
Perhaps the dominance and self-confident serenity of Monica as the pivotal figure in the family are deceptive. In Book IX of the Confessions, Augustine tells us about her childhood: "The rod of Thy Christ, the discipline of Thine only Son in a faithful household, a sound member of Thy church, instructed her in Thy fear" (IX, viii, 17). Parental love in her own family seems to have been masked by discipline and the fear of Christ. Although Monica appreciates her mother's diligence and industry, her parents do not appear to have played a direct and personal role in the upbringing and education of their children. Monica and her sisters were left in the care of an old spinster, a confidante of their father's, who disciplined them with devout severity:

Except during frugal meals the parental table, they were not permitted to drink even water, even though they might be parched, thus preventing the formation of a bad habit. This was accompanied by a wise statement: "You now drink water only because you are not in charge of the wine; however, when you are married and become the mistress of the storerooms and wine cellars, water will lose its appeal, but the habit of drinking will continue. By this system of giving practical advice and commanding by means of her authority, she reined in the greediness of the younger years and moulded that thirst of the girls, according to the measure of virtue, so that, eventually, that which was unfitting was also unpleasing (IX, viii, 17).

Despite being brought up to fear wine, or perhaps just because of it, Monica is overcome by a lust for wine which is getting worse and worse. Where first she took just a sip from the jug, she later greedily drinks full tankards (IX, viii, 18). Her addiction to drink represents a need to be fed, a desire to escape the reality of inadequacy and disparagement (Schmidbauer 1977). Her drinking problem does not go unnoticed; a female slave with whom she is quarrelling, disdainfully calls her a wine-bibber (IX, viii, 18). In a situation like this, in which the parents are remote and the upbringing is characterised by distrust, it is virtually impossible to redeem the child's self-esteem. A fundamental sense of insecurity pervades the child's life. Monica perceives the maid's reproach as a threat to her sense of self, she experiences her public exhortation as a narcissistic injury.

Monica, mother of Augustine, feels rejected-not only by her parents, governesses and maids, but also by the man she is later to marry. Patricius leaves her alone to pursue his own pleasures elsewhere. Monica can only hold out by living her life according to that strict system of Christian norms and values which has been so forcefully instilled in her. Her conscience rather than her needs and desires becomes the dominant force in her life. By living a life of moral rectitude, she can evade the distressing confrontation with an ambiguous reality. She attempts to convert her husband with her high moral precepts: "speaking to him of Thee through her behaviour, in which Thou didst make her beautiful, reverently lovable, and wonderful to her husband" (IX, ix, 19).

However, when the Ego must be strengthened by identifying with the Superego it loses its ability to empathize with the fate of others. Monica, having being more or less deprived of personal affirmation or support, is unable to empathize with the motives and inadequacies of others, let alone gauge or sense what they feel. Children who grow up in a climate where there is no respect or tolerance for their feelings and desires are narcissistically deprived. For the rest of their lives, they look for what their parents could never be for them: someone who is constantly available, who understands them, takes them seriously, admires them and accepts them as they are (Miller 1979). Such children, even when they have become parents themselves, are driven by the compulsion to have their need for recognition and affirmation satisfied in all kinds of surrogate ways. Their own children are the most suitable means of achieving this. From what Augustine has written about his 
mother in his Confessions one may easily gain the impression that Monica's relationship with her son is characterized by the satisfaction by proxy of narcissistic needs. Augustine has to make up for whatever Monica lacked in love and recognition as a child. All that she missed and failed to receive as a child must be provided now that she has become a mother.

At first, Augustine refuses to play the role of the gifted child (cf. Miller 1979). He suffers under his parents' lack of comprehension. In his Confessions, he can only express himself in covert terms:

Or were those things good in fact, in that period: tearfully to be given even harmful things; violently to be offended at free and older human beings, as well as my parents and many other prudent persons besides, because they were not submissive and did not yield to my slightest whim, when striking them I tried my best to harm them for not obeying, though it would have hurt me had they obeyed? (I, vii, 11)

Remembering his childhood, Augustine focuses on the pain he felt when his desires and needs not only went unfulfilled, but were not even recognized as legitimate. Augustine's schooldays were dominated by his parents' ambitions, needs and wishes: "when the only rule of right living set before me as a boy was to obey my teachers, so that I might flourish in this world and excel in the literary arts which pay lip service to the fame of men and to false riches!" (I, ix, 14). This is the first indication that the recognition so sorely missed by the mother, undermining her self-esteem and leaving her in doubt about the social respect to be gained from others, could be gained vicariously through the success of the son. When Augustine is beaten in school because he does not focus eagerly and joyfully on the acquisition of knowledge, and fails to see the advantage of being able to read and write, he prays to God, the great Father. However, "when Thou didst not hear (and this was not done to me for my folly), my beatings, at that time a great and serious evil for me, were laughed at by older men and even by my parents themselves, who desired no evil to befall me" (I, ix, 14). Monica tries to help her son to succeed where she herself has failed: she wants him to command recognition and respect in his own right. Augustine must get on in life and do better than his parents, so that others can say what wonderful parents he must have had and what sacrifices they must have made (II, iii, 5). Monica is rather more interested in what 'people' will say about her as Augustine's mother than in Augustine's well-being as such (IX, xi, 28). Monica hopes that Augustine's prestige and performance will give her the confirmation that she has missed all her life. Her own sense of deprivation prevents her from loving her son for what he is; to satisfy her needs he must live up to the image that she has created of him: her son, the esteemed orator, the Christian professor.

In fact, Monica finds it hard to empathize with her son, for whom she is to shed so many tears. She scoffs at him when he weeps after being beaten in school, she fails to have him baptized when he is critically ill, she does not find him a wife when he is tormented by lust. Also, her attitude towards Augustine's conversion seems to be more influenced by considerations of outward appearances than by concern for her son's spiritual welfare. Although she wants him to be baptized eventually, to become a member of the church, she is at a loss to comprehend his restless search for truth (Kempen 1978, 82). To Augustine, this impression management and dependence on what others might say (II, iii, 8; I, xi, 7) is more of an impediment than an incentive in the decision to convert to his mother's faith (cf. O'Ferrall 1975).

In the Confessions, Monica appears as the mother who sacrifices herself for her family, in quiet resignation to the grief she has to bear: her neglected and loveless youth, her unfaithful and irascible husband, a son who does not want to follow her in her faith. However, she learns to live with the limitations in her life. She "persevered in showing 
marks of respect and this won over her mother-in-law by patience and gentleness" (IX, ix, 20). She brought up her children "being as often in labour with them each time as she saw them wandering away from Thee". She served her son's friends: "almost as if she were a mother to us all, and she served us in such a way that it was as if she were the daughter of us all" (IX, ix, 22).

As such, her maternal love is characterized by moral obligations rather than spontaneous affection. That kind of love is confusing and stifling; it is a love that demands instead of being freely given. Such love is never without an ulterior egoistic motive. Her maternal love appears to be artificial and ambivalent, totally inimical to what it aims to achieve (cf. Drewermann 1989, 280). Monica's maternal love and servitude crave recognition and confirmation. This is why she watches her son's growing independence with deep anxiety. Unlike her husband, she is not happy with his budding sexuality. It frightens her: " She thus experienced a rising feeling of holy fear and trembling for me; though I was not yet one of the faithful" (II, iii, 6). Monica is afraid of Augustine's sexuality because it may draw him away from her. Driven by desire, he will cut the umbilical ties and turn to other women. However, even as a man, he is seductive (II, iii, 7). Kligerman (1957) believes that Monica is afraid of, but perhaps also attracted by, the sexual advances her son may make to her. Is this not the supreme communion and confirmation she can receive from her son? Such communion is unacceptable to her moral being, which is governed by the will, but this does nothing to soothe the ambivalence of her feelings. In her desire to keep her son for herself, even if he "is roaming the streets of Babylon", she does not look for a suitable wife for him. Such a marriage would even be undesirable because it would forever tie the 16-year-old to his social background and preclude an ascent on the social ladder-thus his mother, the sincere Christian woman, justifies her indecision (II, iii, 8; cf. Brown 1990, 390).

Having spent a year at home, frittered away in licentiousness and self-indulgence, Augustine leaves for Carthage to continue his studies at the university. In Carthage, he is subsumed in love (III, i, 1). He plunges headlong into a life of love. He does not resist but succumbs and is caught. Thus he learns that being loved and being in love also involves jealousy, ardour, anger, discord, and fear. In Carthage, Augustine hears that his father has died. In that very same year, he moves in with a girlfriend, a concubine (Brown 1969, 16). When the mother poses a greater threat, when she may make a more forceful appeal, Augustine protects himself by choosing another woman to live with. In Carthage, living together as if married, Augustine is finally loved unrestrainedly and unconditionally. It is a love that he is prepared to fight for, a love that permits him to distance himself from his mother.

Then, reading Cicero, he experiences a desire for wisdom, transparency, and clarity. The Holy Scriptures disappoint him because of their crude style. In his new-found selfesteem he considers them too simple. Therefore, in his search for wisdom, he turns to the teachings of the Manicheans, who draw a sharp line between good and evil. Away from his mother and loved by a woman, Augustine wants to fix boundaries, make distinctions, and escape the ambivalence of unspoken desires and insinuated duties. Perhaps his choice for Manichaeism is also an attempt to defend himself against his mother.

\section{The Prodigal Son}

Monica weeps. She weeps for the son she has lost, who, far from home, is loved by another. A son who keeps well away from her faith. She weeps, even when a travelling bishop assures her that a son of so many tears cannot be lost (III, xii, 21). She dreams that 
Augustine is close to her again. "She saw herself standing on a wooden rule and approaching her was a young man..."(III, xi, 19). This dream predicts the salvation of her son: "...and that wherever she was there also was I". However, after 9 years (cf. Oort 1989, 30), when the bastion of Manichaeism crumbles, when Faust disappoints, he secretly leaves Carthage for Rome (V, vii, 12, 13; V, viii, 14). When his defences fail, he flees. He will still not surrender to his mother's desires. He flees for the "widowed queen of Africa" (Kligerman 1957), as Aeneas once did for Dido (I, xiii, 20, 21). He flees a mother who obstructs his independence, threatens his autonomy, and monopolizes him for her own fulfilment.

However, Monica will not let her son go just like that. When he is appointed professor in Milan, having spent a year in Rome teaching rhetoric, she decides to act. At the pinnacle of his career, she forces her son's surrender. She will no longer wait, crying and hoping, but is prepared to intervene decisively in his life. She follows him to Milan and, once there, forces him to renounce the woman with whom he has been living for 16 years as man and wife, and who is the mother of his son. For the naïve reader of the Confessions, Augustine consents, somewhat abruptly and disappointingly, for reasons of status and career. The parting of Augustine and his mistress, who loved each other deeply, is heartrending, but permanent: "When the woman with whom I had lived for so long was torn from my side because she was a hindrance to my marriage, my heart, to which she clung, was cut and wounded, and the wound drew blood" (VI, xv, 25). A broken heart is the price Augustine pays to enter a marriage that fits his station in life (cf. Brown 1969). His mother takes charge and chooses for him - and herself - a suitable match: an upper-class girl who is not yet marriageable but who will be in 2 years' time. She is still a child, younger than Augustine's son.

Once Augustine's beloved has returned alone to Africa, his mother takes charge of his household and plays mother to his son. Thus Monica becomes the new mistress of Augustine's home. When his mother gets too close to him as a woman, Augustine protects himself by finding a concubine who will provide some sort of sexual consolation. Waiting for his marriage, he fights his last battle for independence (Guardini 1960, 178). In Milan Augustine is surrounded by women who curry favour or suffer his rejection. His mother emerges as the strongest of them all.

In Milan, Augustine is finally overpowered by the mother to whom he feels so close but whom he has resisted for so long for this very reason. Feeling persecuted by his mother, Augustine at last turns to the great Father for support, to a God who is distant and true, allpowerful and omnipresent. Such a distant God who never changes is a reliable God. In his detachment, He will never disappoint him, as did his friends, who died, his father, who let him down, teachers, who beat him, prophets, who failed, a bishop, who did not want to speak to him, and a mother, who seduced him in her suffering (Dittes 1965; cf. Ullman 1989). Embracing his mother's faith, he surrenders his worldly ambitions and opts for a life of celibacy. Yielding to his mother's desires, he will always remain a son and give up attempts to become a separate and autonomous self. Augustine's conversion signifies resignation to dependence. Just when he has reached the age of manhood, he chooses to remain a child. Naturally, his surrender to the mother is preceded by a heroic struggle with sensual love and fleshly lusts. The struggle to achieve asceticism, might be seen as an inverse macho profiling of his own masculinity, his last act of resistance against his mother.

Augustine gives in at last. On hearing a child's voice, he converts to the Son. His facial expression, eyes, cheeks, and the timbre and tone of his voice express the intensity of the battle that is being waged in his "internal dwelling". The emotions in his heart force him to 
go outside, where no one can stop the fierce struggle he is fighting within himself. "I threw myself down under a fig tree, unconscious of my actions and loosened the reins on my tears... and I uttered these wretched words "How much longer, how much longer? "Tomorrow" and "tomorrow"? Why not right now? Why not the end of my shame at this very hour" (VIII, xii, 28). Then, from a nearby dwelling, Augustine hears the voice of a child, a boy or a girl, he is not sure (cf. Kligerman 1957), which tells him: "Take it, read it! Take it, read it!". Augustine picks up the book on the garden table and reads the passage where it falls open, which happens to be Romans 13, Paul's text on turning to the Lord Jesus Christ: "Not in revelry and drunkenness, not in debauchery and wantonness, not in strife and jealousy; but put on the Lord Jesus Christ. And as for the flesh take no thought for its lusts" (VIII, xii, 29). Then, at last, Augustine takes a decision. He surrenders. He renounces the temptations of the adult world. No longer having to face the difficult choices between desire and prohibition, Augustine believes he has at last found his true self. As a child.

His mother is the first-after Alypius, who was with him at the time-whom he informs of the decision he reached when he heard the voice of the child. "We gave her the story of what had happened; she was exultant, triumphant, and she blessed Thee, 'who art able to accomplish far more than we ask to understand" (VIII, xii, 30). Monica triumphs in a joy much richer than she had dared to wish for and much purer than she had expected. Augustine's description of his conversion has hidden sexual connotations: "Thence we go in to my mother...", is the translation by Bakan $(1965,150)$. He renounces the life of desire with a covert reference to carnal knowledge. By identifying with the Son, he sublimates his sexuality in a union with the Church who is the Mother of us all. In accepting the Christian faith, he enters the church which he calls 'our spiritual mother' (VII, I, 1) with his own mother Monica as the ever-present physical representative, "Thou hadst already begun Thy temple and started Thy holy dwelling in my mother's breast” (II, iii, 6). After his experience in the garden, Augustine leaves for Cassiciacum accompanied by his son, his mother, and some friends. This is where he prepares for his baptism. By this time, he has already given up his professorship in rhetoric. The reason given is an asthmatic disorder that impedes his speech, a dolor pectoris. Possibly, this is a psychosomatic disorder, a physical expression of the conflict he was facing: pushed around by an ambitious and desirous mother, while what he really wanted was peace and wisdom. This 'pain in his chest', where his heart is unquiet, impedes his speech, hurts him where he is most vulnerable as a public orator, (Brown 1969, 109-110).

Augustine's desire for a life of philosophical contemplation and emotional quietude can only be fulfilled by conversion to Christianity. One might even hypothesize that the main attraction of Catholicism was that it facilitated and even enabled him to lead a life as a philosopher. For Augustine, a life of wisdom implied total renunciation of earthly desires. Such a break is made possible by putting on Christ, as symbolized in the baptismal ritual. As a Christian, Augustine can enter a new life. His conversion is a paradox of liberation and containment. By choosing Christ, the Son, Augustine resists his mother's earthly ambitions but, at the same time, gives in to her desires and remains accessible to her as a child. As a convert to the Christian faith, Augustine opts for a return to dependence and nonage. Augustine's conversion is ambiguous. It represents an attempt to reinforce his own autonomy, an attempt which succeeded and failed at the same time. It is an act of resistance and an act of surrender.

Hence, Augustine's conversion is not without ambivalence. By choosing Christ, he submits himself, as an obedient son, to the wishes and expectations of his mother. In this respect, his conversion appears to express a fairly serious loss—of individuality, potential 
fatherhood, adult love, progeny. Amid the confusion of desire and temptation, a mixture of unuttered demands and inexpressible wishes of both mother and son brought about by his mother's proximity, the dramatic character of Augustine's apparent sacrifice expresses a powerful resignation to the values of faith and a life of asceticism, but also constitutes a protest, a paradoxical confirmation of his own worth.

In the light of Augustine's attempt to escape the conflict between recognition and submission, between dependency and autonomy, the effects of his conversion seem to be every bit as paradoxical as his motives (cf. Nauta 1989). He believes, with childlike naivety, that he can resort to a life of sexual abstinence and philosophical abstraction by converting to his mother's faith, but in fact the reverse is what happens: he is chosen as bishop, a father of many, and becomes a strict and strong public defender of the faith. Only when Augustine is writing his Confessions in middle age as the Bishop of Hippo Regius, can he admit and accept the ambivalence. In the Confessions, Augustine has come to realize that human beings are destined to be imperfect. Only in the throes of alienation can one yearn for perfection (IX, xiii, 37; XII, xvi, 23). Though Augustine hopes that his conversion will lead to a life of wisdom and social detachment, the Confessions show the impossibility of achieving that ideal. The Confessions are written in a language of intimate proximity, of expectations and anxiety, of struggle and conflict. Augustine writes about the pain of love, about the failure of the will, about sensual desire, about shame and disappointment, about force of habit and the inability to change. The Confessions also reflect on the human deficit in his own life.

\section{Augustine the Cleric}

The relationship between Augustine and his mother has been sketched from various perspectives. In the synchronic analysis, based on the mother's position in a father-ineffective family, I have attempted to show how the composition of that family appears to offer a foolproof basis for mother worship and simultaneously forces the son to assume an exaggerated masculine character to conceal his feminine identification. In his extreme, but insecure machismo profile, Augustine resembles his father, who needs to brag about his sexual conquests. In the second, diachronic, analysis Monica's development from childhood into adulthood is the point of departure. There are indications in the story told by Augustine in his Confessions that she is narcissistically deprived. In her childhood she failed to get proper support for developing a strong and stable ego. Her lack of self-esteem causes her to turn to her son as the provider of the recognition she lacks. Not only must her son act as a powerful substitute for all she has missed, he must also provide support and validation for what she has Become: a devout Christian woman. He must embrace the faith she has made her own. By denying him freedom of choice and autonomous exercise of free will, Monica repeats, in the relationship with her son, her own drama of denial and neglect. In this second interpretation, Augustine emerges as the victim of the suffering Monica, the son who, for the greater good of the mother, is not allowed to follow his own desires and inclinations.

In the Confessions, Augustine comes to life as the child of a father and a mother. He is the child who is punished for the sins of the parents (Brown 1969, 393). Conflicting desires are the hallmark of his existence (Dodds 1928). In order to live with this ambivalence, Augustine has to choose the Church as his Mother and God as his Father. The Church is the ever-accepting, always-comforting guardian of truth, God the Father, the fail-safe God to trust (Dittes 1986). Perhaps Augustine's strongest motive for his conversion was his wish 
to live a life free from seduction and corruption. Such a chaste life is possible within the abstract confines of the church, in surrender and devotion to a distant God, who is radical, transcendent, all-powerful and omniscient, a God who offered his Son for the salvation of all mankind, because He still loves those who were driven from Paradise because of their disobedient, wilful nature. To Augustine, the conception of original sin and the doctrine of grace and redemption are interdependent constructs, which are needed in order to believe in this idea of a Father who can be trusted. Submission and self-denial are the inevitable concomitants of such a faith, which is necessary to deny the ambivalence felt towards the actual parents. As a bishop, Augustine can play a role which-because of its exemplary nature-allows him to both mask and satisfy his personal needs (Burrell 1970, 1990). The ambiguity of the altruistic role (Schmidbauer 1977, 1983; Frederiksen 1974; Capps 1985; Drewermann 1989) is a well-known occupational hazard for those who work in the service professions. Other-directedness is more often used to compensate for personal deficits than to alleviate another's suffering. When altruism as a motive and a skill is driven by narcissistic deprivation - which may have happened in the case of Monica and Augustine-it creates a predisposition for detached and remote helpfulness. Obedient devotion to duty and avoidance of intimacy may push away the lingering pain of childhood, but the innate vulnerability is still revealed in a craving for recognition (Drewermann 1989, 271). The bitter irony of the narcissistic personality is that utter disdain for the feelings and desires of others goes hand in hand with a strong dependence on others for recognition and admiration. For the narcissistically deprived, self-sufficiency is a chronic delusion (Meloy 1986; Rauchfleisch 1983): they cannot do without company, but are afraid of intimacy. Augustine's post-conversion life shows signs of such a discord. Augustine lives in chastity with friends and students in a system of rules and duties. He will never meet women alone (cf. Bavel 1989); with disproportionate vehemence he combats heretics, especially those who postulate ideas such as dignity of the will or human autonomy, or the possibility that some good may come of human effort. Also, the Confessions themselves are an expression of wounded narcissism. Being both a eulogy to the goodness and wisdom of the Lord and an admission of inevitable guilt, they appear to totally subsume any sense of self-importance that Augustine might have left. However, the superabundance of self-reproach could signify a very immodest modesty. Precisely by showing himself as a great sinner (I, xii, 19), incapable of any good, addicted to sin (VII, xvii, 23), to whom an act of goodness only results in misplaced pride, Augustine expresses himself covertly as one who deserves recognition for his apparently meek and remorseful obedience (Curtis 2003). In his Confessions, written in midlife, Augustine is still expressing his need for confirmation. It is a need that was never satisfied by his parents. What they left undone is now assigned to the Great Listener above and to the common readers here below (cf. Gay 1986). Augustine, bishop, preacher and theologian, has been the help and mainstay of a great many people. Many recognized in him the turmoil in their own hearts. Perhaps he has been able to comfort people most by showing his own imperfection.

\section{References}

Bakan, D. (1965). Some thoughts on reading Augustine's Confessions. Journal for the Scientific Study of Religion, 5, 149-152.

Bavel, T. J. van (1989). Augustine's view on women. Augustiniana, 39, 5-53.

Bavel, T. J. van (1997). Maternal aspects in salvation history according to Augustine. Augustiniana, 47, 251-290.

Berg, J. H. van den (1956). Metabletica. Nijkerk: Callenbach. 
Brandle, R., \& Neidhart, W. (1984). Lebensgeschichte und Theologie - ein Beitrag zur psychohistorischen Interpretation Augustins. Theologisches Zeitschrift, 40, 157-180.

Brown, P. (1969). Augustine of Hippo-a biography. London: Faber \& Faber.

Brown, P. (1990). The body and society-men, women and sexual renunciation in early Christianity. London: Faber \& Faber.

Burrell, D. (1970). Reading the Confessions of Augustine: An exercise in theological understanding. Journal of Religion, 50, 327-351.

Burrell, D. (1990). Augustine's Confessions: Speaking responsibly of God and self. In D. Capps \& J. E. Dittes (Eds.), The hunger of the heart: Reflections on the Confessions of Augustine. Society for the Scientific Study of Religion Monograph Series, 8, 303-314.

Capps, D. (1985). Augustine as narcissist: Comments on Paul Rigby's "Paul Ricoeur, Freudianism, and Augustine's Confessions”. Journal of the American Academy of Religion, 53, 115-127.

Capps, D. (1983). Parabolic events in Augustine's autobiography. Theology Today, 40, 260-270.

Capps, D. (1990). Augustine's Confessions: The scourge of shame and the silencing of Adeodatus. In D. Capps \& J. E. Dittes (Eds.), The hunger of the heart: Reflections on the Confessions of Augustine. Society for the Scientific Study of Religion Monograph Series, 8, 69-92.

Capps, D., \& Dittes, J. E. (Eds.) (1990). The hunger of the heart: Reflections on the Confessions of Augustine. Society for the Scientific Study of Religion Monograph Series, 8.

Capps, D., \& Miles, M. R. (1994). Desire and delight: A new reading of Augustine's Confessions. Theology Today, 50, 601-605.

Carroll, M. P. (1986). The cult of the Virgin Mary-psychological origins. Princeton, NJ: Princeton University Press.

Chomarat, J. (1988). Les 'Confessions' de Saint Augustin. Revue Française de Psychanalyse, 52, $153-174$.

Curtis, N. (2003). The time of Confession: Lyotard on Augustine. Time and Society, 12, 189-208.

Daly, L. (1978). Psychohistory and St. Augustine's conversion process. Augustiniana, 28, 231-254.

Dittes, J. E. (1965). Continuities between the life and thought of Augustine. Journal for the Scientific Study of Religion, 5, 130-140.

Dittes, J. E. (1986). Augustine: Search for a fail-safe God to trust. Journal for the Scientific Study of Religion, 25, 57-63.

Dodds, E. R. (1928). Augustine's Confessions: A study of spiritual maladjustment. The Hibbert Journal, 26, $459-473$.

Drewermann, E (1989). Kleriker - Psychogramm eines Ideals. Olten und Freiburg: Walter Verlag.

Elledge, W. P. (1988). Embracing Augustine. Journal for the Scientific Study of Religion, 27, 72-89.

Frederiksen, P. (1974). Augustine and his analysts: The possibility of a psychohistory. Soundings, 61, 206227.

Gay, V. (1986). Augustine: The reader as self-object. Journal for the Scientific Study of Religion, 25, 64-76.

Gilmore, M. M., \& Gilmore, D. D. (1979). Machismo: A psychodynamic approach (Spain). Journal of Psychological Anthropology, 2, 281-300.

Goffman, E. (1959). The presentation of self in everyday life. New York: Anchor Books.

Guardini, R. (1960). De bekering van Aurelius Augustinus. De innerlijke ontwikkeling in zijn 'Belijdenissen'. Hilversum: Paul Brand.

Jonte-Pace, D. (1993). Augustine on the couch: Psychohistorical misreadings of the Confessions. Religion, $23,71-83$.

Kempen-van Dijk, D. M. A. van (1978). Monnica - Augustinus'visie op zijn moeder. Amsterdam: Rodopi.

Kligerman, Ch. (1957). A psychoanalytic study of the Confessions of St. Augustine. Journal of the American Psychoanalytic Association, 5, 469-484.

Meloy, J. R. (1986). Narcissistic psychopathology and the clergy. Pastoral Psychology, 35, 50-55.

Miles, M. R. (1982). Infancy, parenting, and nourishment in Augustine's Confessions. Journal of the American Academy of Religion, 50, 349-364.

Miller, A. (1979). Das Drama des begabten Kindes. Frankfurt am Main: Suhrkamp.

Nauta, R. (1989). Over Bekering. Groningen: Jan Haan.

Newbold, R. F. (1982). Personality structure and response to adversity in early Christian hagiography. Numen, 31, 199-215.

O'Ferrall, M. M. (1975). Monica, a reconsideration. Recherches Augustiniennes, 10, $23-43$.

Oort, J. van (1989). Augustinus - facetten van leven en werk. Kampen: Kok.

Pruyser, P. W. (1966). Psychological examination: Augustine. Journal for the Scientific Study of Religion, 5 , 284-289.

Rauchfleisch, U. (1983). Psychologische Probleme der helfende Berufe. Wege zum Menschen, 35, 77-82.

Rigby, P. (1985). Paul Ricoeur, Freudianism, and Augustine's Confessions. Journal of the American Academy of Religion, 53, 93-114. 
Saunders, G. R. (1981). Men and women of Southern Europe: A review of some aspects of cultural complexity. Journal of Psychological Anthropology, 4, 435-466.

Schmidbauer, W. (1977). Die hilflosen Helfer: uber die seelischen Problematik der helfenden Berufe. Reinbek: Rowohlt.

Schmidbauer, W. (1983). Helfen als Beruf: die Ware Nachstenliebe. Reinbek: Rowohlt.

Ullman, Ch. (1989). The transformed self-the psychology of religious conversion. New York: Plenum Press.

Weintraub, K. J. (1978). The value of the individual: Self and circumstance in autobiography. Chicago: Chicago University Press.

Woolcott, Ph. (1965). Some considerations of creativity and religious experience in St. Augustine of Hippo. Journal for the Scientific Study of Religion, 5, 273-283. 